\title{
Genetic gain according to different selection criteria for agronomic characters in advanced tomato lines
}

\author{
R.R. Finzi ${ }^{1}$, G.M. Maciel $^{2}$, J.V.M. Peixoto ${ }^{1}$, M.P. Momesso ${ }^{2}$, H.G. Peres $^{2}$, \\ M.F. Silva ${ }^{1}$, L.D. Cabral Neto ${ }^{2}$, D.A. Gomes ${ }^{1}$ and M.P.C Martins ${ }^{2}$ \\ ${ }^{1}$ Universidade Federal de Uberlândia, Campus Umuarama, Uberlândia, MG, \\ Brasil \\ ${ }^{2}$ Universidade Federal de Uberlândia, Campus Monte Carmelo, Monte \\ Carmelo, MG, Brasil \\ Corresponding author: R.R. Finzi \\ E-mail: rafaelfinzi@hotmail.com
}

Genet. Mol. Res. 19 (1): gmr18462

Received October 16, 2019

Accepted March 11, 2020

Published March 30, 2020

DOI http://dx.doi.org/10.4238/gmr18462

\begin{abstract}
Tomatoes are an important crop in Brazil. In advanced stages of breeding programs, the capacity to select or reject tomato lines becomes complex. We selected tomato lines comparing different selection strategies. We evaluated 115 advanced tomato lines from the Tomato Germplasm bank of the Federal University of Uberlândia. The following characteristics were evaluated: total chlorophyll content, foliar temperature, number of fruits, yield, distance between the first cluster and the soil, transverse and longitudinal fruit diameter, internode length and total soluble solids. Data was submitted to variance analysis, Scott-Knott's test of means, and selection gains estimates: direct and indirect selection, the classic Smith and Hazel index (SH), the Williams' base index (W), the genotype-ideotype distance index (GID) and the Mulamba and Mock's sum of ranks (MM). According to the Scott-Knott's test, the lines clustered in two groups for the variables number of fruits, yield, and distance between the first cluster and the soil. There was no consistency between the different selection indexes. Selecting 9\% of the lines, total selection gains estimate for selection indexes were $12.57(\mathrm{SH})$, and $38.57 \%(\mathrm{MM})$. With genetic gains more equally
\end{abstract}


distributed among the characters, the MM index is suggested as the most appropriate for advanced stages of tomato breeding programs.

Key words: Solanum lycopersicum; Selection indexes; Plant breeding

\section{INTRODUCTION}

The tomato crop plays important social and economic roles in Brazil. In 2018, the harvested area in this country was about 51 thousand hectares, producing more than 4.1 million tonnes of tomatoes (Food and Agriculture Organization of the United Nations FAO, 2018).In tomato breeding programs, several strategies are used by plant breeders in the selection of superior genotypes. Due to the existence of genetic correlations between characters, selecting is a big challenge. When the selection is practiced aiming at only one characteristic, there are usually favorable or unfavorable changes in the remaining characteristics. Whereas, when the selection is simultaneous, these changes tend to be more generalized within the characters. The possibility to predict gains of a specific selection strategy becomes essential for the success of a breeding program (Bhering et al., 2012).

Overall, performance per se is one of the main standards applied in the selection of superior tomato genotypes. For that matter, the univariate analysis using the Scott-Knott test of means (Scott and Knott, 1974) has been widely used by several authors (Araújo et al., 2016; Borba et al., 2017; Finzi et al., 2017; Maciel et al., 2018; Peixoto et al., 2018). Nevertheless, it is known that this type of selection can be inefficient, because it leads to a superior genotype in no more than one characteristic. In this sense, selection indexes are an excellent alternative, once they associate information from various agronomic characters and make possible to attribute selection weights to the most relevant characteristics.

Among the selection indexes, the following can be remarked: the classic Smith (1936) and Hazel (1943) index (SH), the Williams' (1962) base index (W), the genotypeideotype distance index (Cruz, 2012) (GID) and the index based on the Mulamba and Mock's sum of ranks (1978) (MM). The SH and the W indexes differ mainly in the combination format and in the weighting between the characters. The GID index distinguishes itself for enabling the determination of desired values to each variable, while the MM index doesnot requires establish economic weights and estimating variance and covariance (Rezende et al., 2014). All these indexes provide genetic gain estimations resulting from selection.

Selection indexes have been widely studed in diverse cultivated species, such as alfalfa (Vasconcelos et al., 2010), assai palm (Teixeira et al., 2012), passion fruit (Rosado et al., 2012), maize (Freitas et al., 2013), potato (Terres et al., 2015), and soybean (Leite et al., 2016; Bizari et al., 2017). According to Merk et al. (2012), selection indexes have potential for use in tomato breeding programs aiming at both yield and quality characteristics. However, there are few mentions in the literature regarding the comparison of different selection indexes in advanced stages of tomato breeding programs.

Therefore, our main goal of this article was to compare various selection indexes for determining superior tomato lines.

\section{MATERIAL AND METHODS}


The experiment was carried out from May to July, 2018 at the Vegetable Research Stationof the Federal University of Uberlândia, Monte Carmelo City, Minas Gerais State,

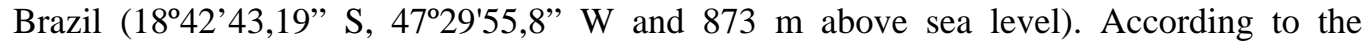
Köppen's classification, the climate is Aw type, characterized by rainy and hot summers and dry winters (Da Motta et al., 2004). The open-air mean temperature in Monte Carmelo city varied from 23.2 (May 13) to $14.1^{\circ} \mathrm{C}$ (May 20) but, in general, it was close to $20^{\circ} \mathrm{C}$ during all the experiment.

The evaluated genetic material was 115 advanced tomato lines from the Tomato Germplasm Bank of the Federal University of Uberlândia. The lines were sowed in polystyrene trays (200 cells) on March 1, 2018.

Plants were grown in a hoop-style greenhouse $(7 \times 21 \mathrm{~m})$, with $4 \mathrm{~m}$ ceiling height, covered by a 150-micron polyethylene roof, treated against ultraviolet rays, and white antiaphid screens as lateral curtains walls. The lines were transplanted into the soil 31 days after the sowing. The soil presented the following characteristics: $\mathrm{pH}\left(\mathrm{H}_{2} \mathrm{O}\right)=5.9 ; \mathrm{P}$ available $=$ $30.1 \mathrm{mg} . \mathrm{dm}^{-3} ; \mathrm{K}=0.22$ cmolc. $\mathrm{dm}^{-3} ; \mathrm{Ca}^{+2}=2.8$ cmolc. $\mathrm{dm}^{-3} ; \mathrm{Mg}=1.0 \mathrm{cmolc} . \mathrm{dm}^{-3} ; \mathrm{H}^{+} \mathrm{Al}=$ $3.40 \mathrm{cmolc} . \mathrm{dm}^{-3}$; organic matter $=4.2 \mathrm{dag} \mathrm{Kg}$; index SMP $=3.4 ; \mathrm{Al}=0.0 \mathrm{cmolc} . \mathrm{dm}^{-3}$; CTC pH $7.0=7.42 \mathrm{cmolc} . \mathrm{dm}^{-3} ;$ Copper $=2.3 \mathrm{mg} \cdot \mathrm{dm}^{-3} ;$ Zinc $=6.6 \mathrm{mg} \cdot \mathrm{dm}^{-3}$ and Manganese $=6.6 \mathrm{mg} \cdot \mathrm{dm}^{-3}$. Throughout the experiment, the cultural treatments followed the recommendations for tomato crops grown in protected environments (Heuvelink, 2018). The plants were supported by a stake using a string weave system.

The experiment was installed in the randomized block design with 115 treatments (advanced lines) and two replications. The experimental plots consisted of six plants, grown in the spacing of $0.2 \times 1.0 \mathrm{~m}$, totalling 1380 plants inside the greenhouse.

The harvests were performed weekly, from June8 to July 27, 2018, totalling eight harvests. The fruits from each experimental plot were harvested in a full maturity stage (fully ripe fruit) and the following agronomic characters were assessed:

Total chlorophyll content (Soil Plant Analysis Development index-SPAD) (TC): obtained by five readings with a portable chlorophyll meter, Minolta SPAD-502 model (Jiang et al., 2017), in 2 central plants in the plot. The measurement was performed at a distance of $0.02 \mathrm{~m}$ from the edge and $0.05 \mathrm{~m}$ from the central leaves vein, followed by the calculation of means.

Foliar temperature $\left({ }^{\circ} \mathrm{C}\right)(\mathrm{FT})$ : obtained with an infrared pyrometer, B-max model, in 2 central plants in the plot. The measurement was taken in five leaves per plant, located in the median part of the tomato, with a $15 \mathrm{~cm}$ distance between the gadget and the leaves, followed by the calculation of the mean. The time of readings was between 12:00 and14:30, and performed on a non-cloudy day.

Number of fruits plant ${ }^{-1}(\mathrm{NF})$ : ratio between the total number of fruits and the number of plants in the plot.

Yield $\left(\mathrm{kg}\right.$ plant $\left.{ }^{1}\right)(\mathrm{YLD})$ : ratio between the weight of harvested fruits and the number of plants in the plot.

Distance between the first cluster and the soil $(\mathrm{cm})(\mathrm{DC})$ : distance between the first cluster and the soil, measured with a ruler $(\mathrm{cm})$, in the two central plants in the plot, followed by the calculation of the mean.

Transverse fruit diameter ( $\mathrm{cm}$ ) (TD): measured with a pachymeter in the transverse median part of the fruit. Ten fruits from the central part of the plot were used, followed by the calculation of the mean. 
Longitudinal fruit diameter (cm) (LD): measured with a pachymeter in the longitudinal median part of the fruit. Ten fruits from the central part of the plot were used, followed by the calculation of the mean.

Internode length $(\mathrm{cm})(\mathrm{I})$ : length between every node of the plant, since the beginning of the first fork in the stem until the first leaf below the last inflorescence. Internode lengths were measured with a ruler $(\mathrm{cm})$ on the two central plants from each plot, followed by the calculation of the mean.

Total soluble solids ( ${ }^{\circ} \mathrm{Brix}$ ) (TSS): obtained as the mean of 15 fruits harvested from each cluster on the two central plants from each plot. After harvesting, the tomatoes were crushed in a blender and analyzed for total soluble solids using a Portable Digital Refractometer (Atago PAL $^{-1} 3810$ ).

The obtained data was analyzed by two distinctive ways: univariate analysis (test of means) and selection indexes (selection gain estimation). For the univariate analysis, data was submitted to analysis of variance (F test, $\mathrm{P}<0.05)$ and the means were compared by the Scott-Knott test $(\mathrm{P}=0.05)$. For the selection gains estimations, $9 \%$ of the genotypes were selected with the direct and indirect selection methods; the classical index proposed by Smith (1936) and Hazel (1943) (SH), the Mulamba and Mock's sum of ranks (1978) (MM), Williams' base index (1962) (W); and the genotype-ideotype distance index (Cruz, 2012) (GID). The selection criteria were to reduce I and increase the remaining characters. For all the indexes, an economic weight equivalent to 1 was adopted for all characters, except for yield and total soluble solids, which adopted economic weight 2. Besides, for the GID index, the optimal values and the inferior and superior limits were determined as most desired for the crop. All the analysis were conducted using the software Genes (Cruz, 2013).

\section{RESULTS}

According to the variance analysis (ANOVA), the advanced tomato lines could be weredifferentiated ( $\mathrm{F}$ test, $\mathrm{P}<0.05$ ) by foliar temperature, number of fruits, yield, distance between the first cluster and the soil, transverse fruit diameter, and internode length (Table 1). Total soluble solids, longitudinal fruit diameter, and total chlorophyll content in the leaves were statistically equal among the genotypes, with average values of $6.12\left({ }^{\circ} \mathrm{Brix}\right) ; 5.4$ $(\mathrm{cm})$ and 58.2 (SPAD index), respectively. Using the Scott-Knott test $(\mathrm{P}<0.05)$, significant differences were identified only for the number of fruits, yield, and distance between the first cluster and the soil (Table 1).

Considering the variables with significant effect according to the Scott-Knott test (number of fruits, yield, and distance between the first cluster and the soil variables), the advanced lines were segregated in two groups (Table 1). Overall, the average values between the groups were 20.8 versus 14.3 for the number of fruits perplant (31\% difference among groups); 1.5 versus 0.9 kilograms for yield (40\% difference among groups); and 47.2 versus 58.6 centimeters for thedistance between the first cluster and the soil ( $20 \%$ difference among groups).

Univariate analysis (Scott-Knott test) does not allow a conclusive visualization of the genetic variability among the genotypes. The non-detection of significant differences in some variables in the test may have occurred due to the large quantity of data, the amplitude proportion of the differences between treatments, as well as the small number of 
replications. It is important to highlight that in breeding programs with a large number of treatments, it is occasionally necessary to reduce the number of replications by reason of the limited number of available seeds, time, space or other resources necessary to execution of experiments. Thus, using alternative selection techniques is essential, especially considering an experiment with a large number of treatments. In this case, methods for estimating genetic gain can be excellent tools in the selection of superior genotypes.

Table 1: Means obtained for nine agronomic characteristics, evaluated in 115 advanced tomato lines.

\begin{tabular}{|c|c|c|c|c|c|c|c|c|c|c|c|c|c|c|c|c|c|c|c|}
\hline Gen $^{1}$ & $\mathrm{TC}^{2}$ & FT* & NF* & YLD* & DC* & TD* & LD & $I^{*}$ & TSS & Gen $^{1}$ & $\mathbf{T C}^{2}$ & FT* & $\mathrm{NF}^{*}$ & YLD* & DC* & TD* & LD & $I^{*}$ & TSS \\
\hline 1 & 52.3 & 21.5 & $11.6 \mathrm{~b}$ & $0.9 \mathrm{~b}$ & $62.0 \mathrm{a}$ & 5.1 & 5.8 & 11.2 & 4.6 & 38 & 62.8 & 22.0 & $20.3 \mathrm{a}$ & $1.9 \mathrm{a}$ & $42.8 \mathrm{~b}$ & 6.5 & 4.3 & 8.5 & 8.6 \\
\hline 2 & 48.5 & 21.9 & $21.5 \mathrm{a}$ & $1.7 \mathrm{a}$ & $66.3 \mathrm{a}$ & 5.2 & 5.6 & 9.6 & 4.9 & 39 & 60.0 & 22.3 & $19.6 \mathrm{a}$ & $1.2 \mathrm{a}$ & $44.3 \mathrm{~b}$ & 5.6 & 4.4 & 8.2 & 5.2 \\
\hline 3 & 48.2 & 22.0 & $22.9 \mathrm{a}$ & $1.3 \mathrm{a}$ & $53.3 \mathrm{a}$ & 4.8 & 4.8 & 8.6 & 5.0 & 40 & 59.2 & 22.1 & $14.0 \mathrm{~b}$ & $1.4 \mathrm{a}$ & $47.3 \mathrm{~b}$ & 6.3 & 5.0 & 9.2 & 5.7 \\
\hline 4 & 51.5 & 22.3 & $24.8 \mathrm{a}$ & $1.6 \mathrm{a}$ & $56.8 \mathrm{a}$ & 5.4 & 5.4 & 9.1 & 4.8 & 41 & 54.6 & 21.6 & $29.0 \mathrm{a}$ & $1.2 \mathrm{a}$ & $56.8 \mathrm{a}$ & 4.4 & 7.9 & 8.2 & 6.3 \\
\hline 5 & 53.1 & 21.4 & $14.2 \mathrm{~b}$ & $1.0 \mathrm{~b}$ & $51.3 \mathrm{~b}$ & 4.5 & 9.2 & 9.8 & 5.6 & 42 & 52.3 & 21.5 & $20.4 \mathrm{a}$ & $0.7 \mathrm{~b}$ & $64.0 \mathrm{a}$ & 3.7 & 9.8 & 8.3 & 7.7 \\
\hline 6 & 57.6 & 22.1 & $14.9 \mathrm{~b}$ & $1.2 \mathrm{a}$ & $59.8 \mathrm{a}$ & 5.4 & 5.3 & 7.1 & 5.7 & 43 & 54.0 & 21.9 & $8.1 \mathrm{~b}$ & $0.5 \mathrm{~b}$ & $68.8 \mathrm{a}$ & 5.6 & 5.0 & 9.5 & 6.8 \\
\hline 7 & 52.5 & 22.1 & $17.5 \mathrm{~b}$ & $0.9 \mathrm{~b}$ & $51.0 \mathrm{~b}$ & 4.2 & 4.9 & 10.0 & 6.7 & 44 & 55.6 & 21.8 & $13.0 \mathrm{~b}$ & $1.1 \mathrm{~b}$ & $50.8 \mathrm{~b}$ & 5.5 & 4.9 & 8.7 & 5.5 \\
\hline 8 & 50.3 & 22.3 & $15.7 \mathrm{~b}$ & $0.7 \mathrm{~b}$ & $56.8 \mathrm{a}$ & 4.8 & 4.7 & 8.5 & 4.9 & 45 & 50.0 & 22.1 & $12.0 \mathrm{~b}$ & $0.8 \mathrm{~b}$ & $49.8 \mathrm{~b}$ & 5.0 & 5.1 & 7.4 & 6.2 \\
\hline 9 & 50.7 & 21.9 & $15.5 \mathrm{~b}$ & $1.4 \mathrm{a}$ & $53.4 \mathrm{a}$ & 6.0 & 8.2 & 8.8 & 4.9 & 46 & 54.3 & 21.6 & $13.4 \mathrm{~b}$ & $1.0 \mathrm{~b}$ & $48.8 \mathrm{~b}$ & 5.8 & 5.2 & 8.7 & 5.4 \\
\hline 10 & 63.3 & 21.3 & $16.5 \mathrm{~b}$ & $1.2 \mathrm{~b}$ & $50.0 \mathrm{~b}$ & 5.3 & 4.2 & 8.6 & 4.9 & 47 & 54.1 & 21.5 & $17.9 \mathrm{a}$ & $1.1 \mathrm{~b}$ & $54.0 \mathrm{a}$ & 5.4 & 5.4 & 8.0 & 5.9 \\
\hline 11 & 62.5 & 21.5 & $15.0 \mathrm{~b}$ & $1.2 \mathrm{a}$ & $59.0 \mathrm{a}$ & 6.0 & 5.1 & 9.0 & 5.5 & 48 & 48.8 & 22.1 & $15.6 \mathrm{~b}$ & $0.9 \mathrm{~b}$ & $48.8 \mathrm{~b}$ & 3.7 & 5.7 & 10.4 & 6.0 \\
\hline 12 & 56.8 & 21.5 & $23.4 \mathrm{a}$ & $1.2 \mathrm{a}$ & $56.1 \mathrm{a}$ & 6.3 & 5.2 & 7.7 & 6.7 & 49 & 59.6 & 22.0 & $20.3 \mathrm{a}$ & $0.9 \mathrm{~b}$ & $54.3 \mathrm{a}$ & 4.5 & 3.7 & 7.5 & 6.0 \\
\hline 13 & 52.8 & 21.5 & $19.2 \mathrm{a}$ & $1.4 \mathrm{a}$ & $54.8 \mathrm{a}$ & 5.5 & 5.2 & 10.3 & 5.9 & 50 & 111.9 & 21.9 & $10.9 \mathrm{~b}$ & $0.6 \mathrm{~b}$ & $57.5 \mathrm{a}$ & 6.4 & 5.4 & 10.4 & 6.4 \\
\hline 14 & 59.4 & 21.2 & $17.0 \mathrm{~b}$ & $1.1 \mathrm{~b}$ & $43.6 \mathrm{~b}$ & 5.9 & 4.9 & 8.7 & 4.9 & 51 & 59.7 & 22.1 & $12.7 \mathrm{~b}$ & $1.0 \mathrm{~b}$ & $46.5 \mathrm{~b}$ & 5.1 & 4.4 & 7.6 & 6.0 \\
\hline 15 & 55.7 & 21.4 & $23.8 \mathrm{a}$ & $1.4 \mathrm{a}$ & $47.0 \mathrm{~b}$ & 5.1 & 4.0 & 14.4 & 4.7 & 52 & 57.4 & 22.2 & $13.9 \mathrm{~b}$ & $0.9 \mathrm{~b}$ & $48.8 \mathrm{~b}$ & 6.2 & 5.3 & 8.1 & 6.5 \\
\hline 16 & 57.8 & 21.7 & $20.2 \mathrm{a}$ & $0.8 \mathrm{~b}$ & $56.4 \mathrm{a}$ & 4.5 & 3.8 & 8.9 & 6.4 & 53 & 56.1 & 21.6 & $17.5 \mathrm{~b}$ & $1.5 \mathrm{a}$ & $46.3 \mathrm{~b}$ & 5.7 & 4.7 & 7.7 & 5.9 \\
\hline 17 & 57.7 & 21.4 & $18.8 \mathrm{a}$ & $0.9 \mathrm{~b}$ & $62.6 \mathrm{a}$ & 5.0 & 4.6 & 9.6 & 5.9 & 54 & 57.3 & 22.0 & $18.9 \mathrm{a}$ & $1.4 \mathrm{a}$ & $49.3 \mathrm{~b}$ & 6.7 & 5.1 & 8.5 & 6.4 \\
\hline 18 & 47.7 & 21.3 & $20.0 \mathrm{a}$ & $1.5 \mathrm{a}$ & $54.0 \mathrm{a}$ & 4.7 & 5.6 & 10.7 & 6.4 & 55 & 57.9 & 22.2 & $27.7 \mathrm{a}$ & $1.2 \mathrm{a}$ & $44.3 \mathrm{~b}$ & 5.7 & 4.7 & 8.3 & 5.0 \\
\hline 19 & 51.4 & 21.1 & $15.6 \mathrm{~b}$ & $0.6 \mathrm{~b}$ & $46.3 \mathrm{~b}$ & 3.9 & 4.5 & 11.5 & 7.1 & 56 & 54.3 & 22.3 & $13.9 \mathrm{~b}$ & $1.1 \mathrm{~b}$ & $43.5 \mathrm{~b}$ & 5.4 & 5.0 & 9.4 & 5.4 \\
\hline 20 & 48.7 & 21.3 & $14.9 \mathrm{~b}$ & $0.6 \mathrm{~b}$ & $58.5 \mathrm{a}$ & 4.5 & 5.3 & 12.5 & 6.2 & 57 & 56.7 & 22.3 & $19.9 \mathrm{a}$ & $0.9 \mathrm{~b}$ & $34.8 \mathrm{~b}$ & 4.9 & 4.2 & 7.7 & 6.8 \\
\hline 21 & 44.6 & 21.8 & $13.3 \mathrm{~b}$ & $0.7 \mathrm{~b}$ & $71.0 \mathrm{a}$ & 4.9 & 4.6 & 11.0 & 6.1 & 58 & 58.2 & 22.3 & $18.9 \mathrm{a}$ & $1.8 \mathrm{a}$ & $68.0 \mathrm{a}$ & 8.9 & 7.7 & 9.3 & 6.5 \\
\hline 22 & 45.1 & 21.4 & $15.7 \mathrm{~b}$ & $1.1 \mathrm{~b}$ & $59.5 \mathrm{a}$ & 5.1 & 5.6 & 9.2 & 5.5 & 59 & 55.6 & 21.7 & $15.2 \mathrm{a}$ & $1.1 \mathrm{~b}$ & $53.9 \mathrm{a}$ & 6.1 & 5.1 & 8.1 & 6.3 \\
\hline 23 & 54.1 & 21.5 & $14.5 \mathrm{~b}$ & $0.8 \mathrm{~b}$ & $55.6 \mathrm{a}$ & 5.7 & 5.1 & 8.1 & 6.3 & 60 & 53.5 & 22.3 & $21.0 \mathrm{a}$ & $1.5 \mathrm{a}$ & $55.5 \mathrm{a}$ & 7.2 & 6.3 & 8.5 & 5.9 \\
\hline 24 & 57.5 & 21.3 & $20.9 \mathrm{a}$ & $0.8 \mathrm{~b}$ & $64.3 \mathrm{a}$ & 4.1 & 7.3 & 9.6 & 6.0 & 61 & 53.5 & 22.2 & $18.1 \mathrm{a}$ & $0.8 \mathrm{~b}$ & $47.8 \mathrm{~b}$ & 4.8 & 4.1 & 9.0 & 7.0 \\
\hline 25 & 59.5 & 21.8 & $15.3 \mathrm{~b}$ & $0.7 \mathrm{~b}$ & $47.0 \mathrm{~b}$ & 4.9 & 4.1 & 8.0 & 7.1 & 62 & 65.5 & 21.6 & $22.6 \mathrm{a}$ & $1.9 \mathrm{a}$ & $55.0 \mathrm{a}$ & 5.8 & 4.8 & 8.0 & 6.2 \\
\hline 26 & 118.0 & 20.5 & $11.4 \mathrm{~b}$ & $0.9 \mathrm{~b}$ & $68.5 \mathrm{a}$ & 5.3 & 4.9 & 9.2 & 5.6 & 63 & 57.0 & 21.7 & $12.5 \mathrm{~b}$ & $1.5 \mathrm{a}$ & $61.0 \mathrm{a}$ & 7.5 & 6.2 & 8.0 & 6.2 \\
\hline 27 & 61.2 & 21.5 & $13.6 \mathrm{~b}$ & $0.8 \mathrm{~b}$ & $55.8 \mathrm{a}$ & 6.3 & 5.3 & 6.8 & 7.1 & 64 & 61.3 & 21.5 & $17.1 \mathrm{~b}$ & $1.0 \mathrm{~b}$ & $58.0 \mathrm{a}$ & 4.7 & 4.0 & 9.5 & 6.5 \\
\hline 28 & 53.3 & 21.8 & $17.0 \mathrm{~b}$ & $1.2 \mathrm{a}$ & $56.3 \mathrm{a}$ & 6.0 & 5.0 & 8.6 & 6.2 & 65 & 68.0 & 21.2 & $21.8 \mathrm{a}$ & $1.6 \mathrm{a}$ & $51.8 \mathrm{~b}$ & 5.4 & 4.4 & 9.0 & 5.6 \\
\hline 29 & 57.4 & 21.8 & $12.4 \mathrm{~b}$ & $1.0 \mathrm{~b}$ & $62.5 \mathrm{a}$ & 5.4 & 4.5 & 7.8 & 5.4 & 66 & 57.4 & 21.4 & $11.9 \mathrm{~b}$ & $0.7 \mathrm{~b}$ & $56.6 \mathrm{a}$ & 5.9 & 4.8 & 8.6 & 7.6 \\
\hline 30 & 60.0 & 21.7 & $19.0 \mathrm{a}$ & $1.7 \mathrm{a}$ & $63.5 \mathrm{a}$ & 6.0 & 4.8 & 9.1 & 7.2 & 67 & 53.1 & 21.7 & $10.3 \mathrm{~b}$ & $0.7 \mathrm{~b}$ & $59.5 \mathrm{a}$ & 5.4 & 4.3 & 8.3 & 6.4 \\
\hline 31 & 57.9 & 22.2 & $12.6 \mathrm{~b}$ & $0.8 \mathrm{~b}$ & $55.3 \mathrm{a}$ & 5.2 & 3.8 & 8.4 & 6.5 & 68 & 62.6 & 21.5 & $12.7 \mathrm{~b}$ & $1.0 \mathrm{~b}$ & $49.5 \mathrm{~b}$ & 6.7 & 6.3 & 9.4 & 5.8 \\
\hline 32 & 61.9 & 21.5 & $14.3 \mathrm{~b}$ & $1.2 \mathrm{a}$ & $41.5 \mathrm{~b}$ & 6.0 & 5.1 & 7.5 & 6.7 & 69 & 59.3 & 21.3 & $12.8 \mathrm{~b}$ & $0.9 \mathrm{~b}$ & $51.8 \mathrm{~b}$ & 8.2 & 7.6 & 8.2 & 6.4 \\
\hline 33 & 63.0 & 22.1 & $14.4 \mathrm{~b}$ & $1.3 \mathrm{a}$ & $52.3 \mathrm{~b}$ & 6.7 & 5.6 & 7.7 & 6.9 & 70 & 55.5 & 21.4 & $16.9 \mathrm{~b}$ & $1.3 \mathrm{a}$ & $47.0 \mathrm{~b}$ & 7.0 & 9.7 & 8.1 & 6.7 \\
\hline 34 & 59.3 & 22.2 & $26.1 \mathrm{a}$ & $1.9 \mathrm{a}$ & $51.3 \mathrm{~b}$ & 5.2 & 4.1 & 8.1 & 5.3 & 71 & 61.0 & 21.9 & $18.0 \mathrm{a}$ & $1.0 \mathrm{~b}$ & $45.8 \mathrm{~b}$ & 5.2 & 4.5 & 6.4 & 5.1 \\
\hline 35 & 60.6 & 22.3 & $19.5 \mathrm{a}$ & $1.7 \mathrm{a}$ & $56.8 \mathrm{a}$ & 5.8 & 4.7 & 7.6 & 6.7 & 72 & 66.4 & 21.7 & $16.7 \mathrm{~b}$ & $1.5 \mathrm{a}$ & $61.8 \mathrm{a}$ & 6.3 & 5.3 & 8.4 & 6.5 \\
\hline 36 & 63.3 & 21.7 & $20.9 \mathrm{a}$ & $2.6 \mathrm{a}$ & $54.0 \mathrm{a}$ & 7.2 & 5.4 & 8.5 & 6.9 & 73 & 63.5 & 22.2 & $13.3 \mathrm{~b}$ & $1.0 \mathrm{~b}$ & $50.5 \mathrm{~b}$ & 6.1 & 4.7 & 7.6 & 7.8 \\
\hline 37 & 62.2 & 22.0 & $13.0 \mathrm{~b}$ & $1.2 \mathrm{a}$ & $48.0 \mathrm{~b}$ & 5.1 & 4.3 & 7.1 & 7.4 & 74 & 55.2 & 21.9 & $17.2 \mathrm{~b}$ & $1.4 \mathrm{a}$ & $55.0 \mathrm{a}$ & 8.4 & 7.4 & 7.7 & 6.0 \\
\hline
\end{tabular}

${ }^{1}$ The numerals indicate the advanced tomato lines UFU-T. Means followed by distinct letters in the column differ by the Scott-Knott test at 0.05 significance. ${ }^{*}$ Significant by the $\mathrm{F}$ test (ANOVA) at 0.05 significance. ${ }^{2} \mathrm{TC}$ : total chlorophyll (SPAD); FT: foliar temperature $\left({ }^{\circ} \mathrm{C}\right)$; NF: number of fruits (plant ${ }^{-1}$ fruits); YLD: yield $\left(\mathrm{kg} \mathrm{plant}^{-1}\right)$; DC: distance from the first cluster and the soil (cm); TD: transverse fruit diameter $(\mathrm{cm})$; LD: longitudinal fruit diameter $(\mathrm{cm})$; I: Internode length $(\mathrm{cm})$; and TSS: total soluble solids $\left({ }^{\circ}\right.$ Brix $)$.

Direct selection consists of the selection of only one important variable, aiming to obtain maximum genetic gains for such characteristic. Although, focusing in one single character may result on unfavorable gains for other important agronomic characteristics (Cruz, 2012). In this study, direct selection led to the greatest individual gains, but resulted in indirect losses for the remaining characters (Table 2). None of the direct selection led to 
satisfying genetic gains estimations in all the evaluated characteristics. The greatest gain estimation was observed in yield ( $\mathrm{SG}=135.37 \%$ ), by selecting $9 \%$ of the evaluated genotypes, but following a reduction in the number of fruits $(\mathrm{SG}=-37.65 \%)$ and an increased internode length $(\mathrm{SG}=50.94 \%)$.

Table 2. Estimations of selection gain (SG\%) on eight variables, by direct and indirect selection, in 115 advanced tomato lines.

\begin{tabular}{|c|c|c|c|c|c|c|c|c|}
\hline \multirow{2}{*}{ Variables } & \multicolumn{8}{|l|}{ SG\% } \\
\hline & $\mathbf{T C}^{1}$ & FT & NF & YLD & $\overline{D C}$ & TD & LD & I \\
\hline TC & 11.41 & -4.30 & 0.85 & -1.56 & -0.14 & -3.90 & -2.01 & -2.87 \\
\hline FT & -6.89 & 82.77 & -32.25 & 5.38 & -17.74 & 24.06 & -27.97 & 6.16 \\
\hline NF & -14.18 & -7.19 & 95.04 & -37.65 & 6.41 & -9.73 & 7.41 & 0.63 \\
\hline YLD & -36.83 & -17.35 & -18.66 & 135.37 & -44.26 & 13.54 & -21.67 & -40.68 \\
\hline DC & 42.73 & -42.66 & -24.31 & -10.19 & 120.57 & -50.45 & 13.52 & 71.28 \\
\hline TD & -9.44 & 38.45 & -26.01 & -8.28 & 1.05 & 93.58 & -36.29 & -2.92 \\
\hline LD & -16.11 & -5.82 & 2.79 & -15.75 & -6.05 & -5.76 & 48.55 & -4.27 \\
\hline I & 23.62 & -39.59 & -6.47 & 50.94 & -41.72 & -21.97 & -1.86 & -46.12 \\
\hline Total & -5.69 & 4.31 & -9.02 & 118.26 & 18.12 & 39.37 & -20.32 & -18.79 \\
\hline
\end{tabular}

The increase of number of fruits and yield are essential goals in a tomato breeding program. Internode length is also relevant, since it can influence the number of clusters per plant (Finzi et al., 2017). Therefore, selection of superior tomato genotypes should be made considering several characters simultaneously, in order to maximize genetic gains for the greatest number of characteristics as possible (Vasconcelos et al., 2010; Rezende et al., 2014). The selection indexes represent an excellent alternative, allowing simultaneous selection with efficiency (Cruz, 2012; Rosado et al., 2012).

Selection gains estimations (SG\%) obtained for all variables (significant or not according to ANOVA) vary among the selection indexes. Generally, by selecting only $9 \%$ of the superior genotypes (10 advanced lines), the SG varied from 0.30 to $1.57 \%$ for total chlorophyll content; -0.10 to $0.36 \%$ for foliar temperature; -6.83 to $6.31 \%$ for number of fruits; -0.59 to $26.64 \%$ for yield; 2.97 to $11.84 \%$ for distance between the first cluster and the soil; 5.50 to $9.41 \%$ for fruit diameter; -0.63 to $4.76 \%$ for fruit length; and -2.93 to $2.46 \%$ for internode length, among all selection indexes (Table 3). In all the selection strategies, total soluble solids did not show positive or negative estimations of SG, which grants the non-genetic variability of the characteristic among the genotypes.These results differ from the Merk et al. (2012) study: analyzing a processing tomato germplasm, these authors found significant genetic variation for soluble solids.

Considering the desirable characteristics in a tomato breeding program, the greatest estimations for selection gains were observed in the MM index (Table 4), especially for the number of fruits $(\mathrm{SG}=6.31 \%)$ and yield $(\mathrm{SG}=26.64 \%)$. Besides that, there was an estimation of reduction in the internode length $(-2.93 \%)$, a favorable characteristic for tomato crops (Finzi et al., 2017).

Supporting these results, in other papers, when different indexes were compared, the MM index presented the most satisfying results for alfalfa, (Vasconcelos et al., 2010), assai palm (Teixeira et al., 2012), passion fruit (Rosado et al., 2012), maize (Freitas et al., 
2013), potato (Terres et al., 2015), and soybean crops (Bizari et al., 2017). Considering only the area under the disease progress curve of the tomato late blight (Phytophthora infestans) and fruit quality characteristics (total soluble solids and titratable acidity), Nick et al. (2013) also observed greater total estimated gain using the MM index. In the Leite et al. (2016) study, the $\mathrm{W}$ index was the most suitable for soybean advanced lines.

Table 3. Estimations of selection gain (SG\%) obtained for eight variables, in 115 advanced tomato lines with the basic index proposed by Smith and Hazel (SH), the sum of ranks index of Mulamba and Mock (MM), Williams' base index (W), and the genotype-ideotype distance index (GID).

\begin{tabular}{|c|c|c|c|c|c|c|c|c|c|}
\hline Index & $\begin{array}{l}\text { SG\% } \\
\text { TC } \\
\end{array}$ & FT & NF & YLD & DC & TD & LD & I & Total \\
\hline $\mathrm{W}$ & 1.57 & -0.10 & 1.96 & 14.53 & 7.00 & 5.20 & 0.08 & 0.72 & 30.96 \\
\hline SH & 0.30 & 0.00 & -6.83 & -0.59 & 11.84 & 4.72 & 0.67 & 2.46 & 12.57 \\
\hline MM & 0.35 & 0.36 & 6.31 & 26.64 & 2.97 & 5.5 & -0.63 & -2.93 & 38.57 \\
\hline GID & 0.98 & 0.36 & -0.78 & 14.70 & 4.21 & 9.41 & 4.76 & -0.12 & 33.52 \\
\hline
\end{tabular}

1TC: total chlorophyll (SPAD); FT: foliar temperature $\left({ }^{\circ} \mathrm{C}\right)$; NF: number of fruits (plant ${ }^{-1}$ fruits); YLD: yield $\left(\mathrm{kg}\right.$ plant $\left.{ }^{-1}\right)$; DC: distance from the first cluster and the soil $(\mathrm{cm})$; TD: transverse fruit diameter $(\mathrm{cm})$; LD: longitudinal fruit diameter $(\mathrm{cm})$ and I: Internode length $(\mathrm{cm})$.

The $\mathrm{W}$ and GID indexes were similar, allowing total gain of 30.96 and $33.52 \%$, respectively, versus $38.57 \%$ from the MM index. On the other hand, the classical SH index presented undesirable selection gain values, for the characteristics evaluated. Selecting the ten best genotypes proposed by the index, the SG reached from $-6.83,-0.59$ and $2.46 \%$ for number of fruits, yield and internode length, respectively (Table 4).

Once the indexes with the greatest genetic gain estimates are established, it is possible to select the genotypes with agronomic potential. Overall, the greater genetic gains distributed equally within the evaluated characters (especially number of fruits, yield, and internode reduction) were obtained with genotypes selected by the MM index: UFU-T36, UFU-T58, UFU-T35, UFU-T72, UFU-T38, UFU-T30, UFU-T33, UFU-T83, UFU-T62, UFU-T100 (Table 4).

Table 4. Indication of ten superior genotypes of tomato selected by basic index proposed by Smith and Hazel (SH), the sum of ranks index of Mulamba and Mock (MM), Williams' base index (W), and the genotype-ideotype distance index (GID).

\begin{tabular}{llll}
\hline $\mathbf{W}$ & SH & MM & GID \\
\hline UFU-T26 & UFU-T58 & UFU-T36 & UFU-T88 \\
UFU-T50 & UFU-T43 & UFU-T58 & UFU-T58 \\
UFU-T87 & UFU-T63 & UFU-T35 & UFU-T87 \\
UFU-T58 & UFU-T97 & UFU-T72 & UFU-T79 \\
UFU-T100 & UFU-T21 & UFU-T38 & UFU-T72 \\
UFU-T72 & UFU-T92 & UFU-T30 & UFU-T36 \\
UFU-T30 & UFU-T93 & UFU-T33 & UFU-T112 \\
UFU-T36 & UFU-T29 & UFU-T83 & UFU-T63 \\
UFU-T97 & UFU-T2 & UFU-T62 & UFU-T74 \\
UFU-T62 & UFU-T26 & UFU-T100 & UFU-T50 \\
\hline
\end{tabular}

Univariate analysis, such as direct and indirect selection, was not appropriate for efficient selection. The use of genetic gain (SG) can reduce significantly the time and 
resources needed in the selection of potential genotypes in a breeding program (Heffener et al., 2011). Therefore, the use of selection indexes becomes an essencial strategy.

There was no consistency between the different selection indexes and the SH index was not suitable for selecting the lines. The $\mathrm{W}$ and GID indexes presented inferior values of total SG estimations in comparison to the MM index. Thus, the MM index is suggested as the most appropriate to select advanced tomato lines.

\section{ACKNOWLEDGMENTS}

The authors would like to thank the Federal University of Uberlândia (UFU), the Minas Gerais State Research Foundation (FAPEMIG), the National Council for Scientific and Technological Development $(\mathrm{CNPq})$, and the Coordination for the Improvement of Higher Education Personnel (CAPES) for funding this research.

\section{CONFLICTS OF INTEREST}

The authors declare no conflict of interest.

\section{REFERENCES}

Araujo JC, Telhado SFP, Sakai RH, Ledo CAS, et al. (2016). Univariate and multivariate procedures for agronomic evaluation of organically grown tomato cultivars. Hortic. Bras. 34: 374-380.

Bhering LL, Laviola BG, Salgado CC, Barrera Sanchez CF, et al. (2012). Genetic gains in physic nut using selection indexes. Pesq. Agropec. Bras. 47: 402-408.

Bizari EH, Val BHP, Pereira EDM, Mauro AOD, et al. (2017). Selection indices for agronomic traits in segregating populations of soybean. Rev. Ciênc. Agron. 48: 110-117.

Borba MEA, Maciel GM, Marquez GR, Fraga Junior EF, et al. (2017). Genetic diversity and selection in tomato genotypes under water stress induced by mannitol. Biosci. J. 33: 592-600.

Cruz CD (2013). Genes: a software package for analysis in experimental statistics and quantitative genetics. Acta Sci. 35: 271-276.

Cruz CD, Regazzi AJ and Carneiro PCS (2012). Modelos biométricos aplicados ao melhoramento genético. 4th edn. Universidade Federal de Viçosa, Viçosa.

Da Motta PEF, Baruqui AM, Dos Santos HG (2004). Boletim de pesquisa e desenvolvimento: Levantamento de média intensidade dos solos da região do Alto Paranaíba, Minas Gerais. EMBRAPA, Rio de Janeiro.

Food and Agriculture Organization of the United Nations - FAO (2018). FAOSTAT. Available at:[http://www.fao.org/faostat/en/\#data/QC] Accessed 2 March, 2020.

Finzi RR, Maciel GM, Silva EC, Luz JMQ, et al. (2017). Agronomic performance of mini-tomato hybrids from dwarf lines. Ciênc. Agrotec. 41: 15-21.

Freitas ILJ, Amaral Junior AT, Viana AP, Pena GF, et al. (2013). Ganho genético avaliado com índices de seleção e com REML/Blup em milho-pipoca. Pesq. Agropec. Bras. 48: 1464-1471.

Hazel LN (1943). The genetic basis for constructing selection indexes. Genetics 28: 476-49.

Heffner EL, Jannink J and Sorrells ME (2011). Genomic Selection Accuracy using Multifamily Prediction Models in a Wheat Breeding Program. Plant Genome. 4: 65-75.

Heuvelink E (ed) (2018). Tomatoes. 2nd edn. CABI Publishing, Wallingford.

Jiang C, Johkan M, Hohjo M, Tsukagoshi S, et al. (2017), A correlation analysis on chlorophyll content and SPAD value in tomato leaves. Hort. Research. 71: 37-42.

Leite WS, Pavan BE, Matos Filho CHA, Alcantara Neto F, et al. (2016). Genetic parameters estimation, correlations and selection indexes for six agronomic traits in soybean lines F8. Comun. Sci. 7: 302-310.

Maciel GM, Finzi RR, Carvalho FJ, Marquez GR, et al. (2018). Agronomic performance and genetic dissimilarity among cherry tomato genotypes. Hortic. Bras.36: 167-172.

Merk HL, Yarnes SC, Deynze AV, Tong N, et al. (2012). Trait Diversity and Potential for Selection Indices Based on Variation Among Regionally Adapted Processing Tomato Germplasm. J. Amer. Soc. Hort. Sci.137: 427-437.

Mulamba NN and Mock JJ (1978). Improvement of yield potential of the Eto Blanco maize (Zea mays L.) population by breeding for plant traits. Egypt. J. Genet. Cytol. 7: 40-51. 
Nick C, Laurindo BS, Almeida VS, Freitas RD, et al. (2013). Seleção simultânea para qualidade do fruto e resistência à requeima em progênies de tomateiro. Pesq. Agropec. Bras.48: 59-65.

Peixoto JVM, Almeida RS, Rocha JPR, Maciel GM, et al. (2018). Hierarchical and optimization methods for the characterization of tomato genotypes. Rev. Bras. Eng. Agríc. Ambient. 23: 27-31.

Rezende JC, Botelho CE, Oliveira ACB, Silva FL, et al. (2014). Genetic progress in coffee progenies by different selection criteria. Coffee Sci. 9: 347-353.

Rosado LDS, Santos CEMD, Bruckner CH, Nunes ES, et al. (2012). Simultaneous selection in progenies of yellow passion fruit using selection indices. Rev. Ceres. 59: 95-101.

Scott AJ and Knott MA (1974). A cluster analysis method for grouping means in the analysis of variance. Biometrics 30: 07-512.

Smith HF (1936). A discriminant function for plant selection. Ann. Eugen.7: 240-250.

Teixeira DHL, Oliveira MSP, Gonçalves FMA and Nunes JAR (2012). Índices de seleção no aprimoramento simultâneo dos componentes da produção de frutos em açaizeiro. Pesq. Agropec. Bras. 47: 237-243.

Terres LR, Lenz E, Castro CM and Pereira AS (2015). Estimativas de ganhos genéticos por diferentes índices de seleção em três populações híbridas de batata. Hortic. Bras. 33: 305-310.

Vasconcelos ES, Ferreira RP, Cruz CD, Moreira A, et al. (2010). Estimativas de ganho genético por diferentes critérios de seleção em genótipos de alfafa. Rev. Ceres. 57: 205-210.

Williams JS (1962). The evaluation of a selection index. Biometrics. 18: 375-393. 